\title{
Comparative Histological Study on the Effect of Mesenchymal Stem Cell and Losartan on Cardiac Injury Induced by Doxorubicin in Male Albino Rats
}

\section{Original Article}

\author{
Somaya Saad Zaghloul', Rahma Kamal El-din Abo-El nour', Marwa Mohamed \\ Abdel Fattah', Dalia Ibrahim Ismail ${ }^{1}$
}

${ }^{1}$ Histology Department, Faculty of Medicine, Cairo University, ${ }^{2}$ Misr University for Science and Technology Cairo, Egypt

\begin{abstract}
Introduction: Cardiovascular disease is the leading cause of death worldwide. Mesenchymal stem cells (MSCs) could be a promising therapy for treating cardiomyopathy.

Aim of Work: To compare the therapeutic effects of MSCs and losartan (LOS) on doxorubicin (DOX) induced cardiomyopathy. Material and Methods: Thirty-nine male albino rats were divided into group I as a control group, group II received DOX $5 \mathrm{mg} / \mathrm{kg}$ ip once, group III received DOX as in group II 'after 3 weeks LOS was given $30 \mathrm{mg} / \mathrm{kg}$ daily by gastric tube for 3 weeks and group IV received DOX as in group and after 3 weeks rats injected by $1 \mathrm{ml}$ of Paul Karl Haron (PKH)26 labeled MSCs iv. Blood samples were collected for estimating the creatine kinase-myocardial band (CK-MB) value. Cardiac muscle sections from all groups were examined by fluorescence microscope. All sections were processed for histological study using Hx\&E and Masson's trichrome stains in addition to immunohistochemical staining for Cx43 and CD44.Morphometric and statistical studies were done.

Results: Group II revealed fragmented muscle fibers and cytoplasmic vacuolation in addition to loss of transverse striation. These changes were confirmed by significant increase in the mean value of CK-MB and the mean area $\%$ of collagen fibers when compared to all other groups. In group III, regression of the previous changes was noticed and there was a significant decrease in the mean area \% of collagen fibers when compared to group II. Group IV cardiomyocytes appeared healthy with normal arrangement and non-significant difference in mean area $\%$ of collagen fibers versus the control. Studying all groups immunohistochemically, revealed increase in positive reactions in LOS and SC groups when compared to DOX group with more increase in SC group than LOS group.

Conclusion: Losartan improves cardiac injury with little effect on cardiac regeneration. MSCs have promising potential in cardiac regeneration.
\end{abstract}

Received: 24 February 2019, Accepted: 17 April 2019

Key Words: CD44; Cx 43; DOX; LOS; MSCs.

Corresponding Author: Marwa Mohamed Abdel Fattah, MD, Histology Department, Faculty of Medicine, Misr University for Science and Technology, Cairo, Egypt, Tel.: +20 1221453070, E-mail: drmarwa.m.abdelfattah@gmail.com

ISSN: 1110-0559, Vol. 42, No. 4

\section{INTRODUCTION}

Cardiovascular diseases seem to be the major cause of disability and death in the whole world ${ }^{[1]}$.

Doxorubicin (DOX) is a potent and widely used anthracycline chemotherapeutic agent used in treatment of several malignancies. The clinical use of this drug is limited because of its cardiotoxicity. The most frequent form of cardiotoxicity usually presented as a dilated cardiomyopathy ${ }^{[2]}$.

Losartan (LOS) is an angiotensin II type 1 receptor (AT1) antagonist is commonly prescribed for the treatment of hypertension and its sequelae as pulmonary fibrosis and post infarction cardiomyopathy ${ }^{[3]}$.
Mesenchymal stem cells (MSCs) are multipotent stem cells that can be isolated from bone marrow, umbilical cord and many other tissues and have the potential to differentiate into several cell types such as mesodermal lineage cells e.g. adipocyte, osteoblast and myogenic lineage $\mathrm{e}^{[4]}$.

Preclinical studies indicate that administered MSCs significantly ameliorated the cardiotoxic manifestations as shown by biochemical, functional and structural cardiac improvement and accelerate repaii ${ }^{[5]}$.

The current study was designed to evaluate and compare the possible therapeutic regenerative effect of both MSCs and LOS on experimentally induced cardiotoxicity using DOX in male albino rats. 


\section{MATERIALS AND METHODS}

\section{I-Drugs}

\section{- Doxorubicin}

Trade name Adriamycin, manufactured by Pharmacia Italia Co., in a form of vials containing (each $10 \mathrm{mg}$ ). It was dissolved in distilled water.

\section{- Losartan}

Trade name Cozaar, manufactured by Amriya Pharmaceutical Industries Alexandria-Egypt, in form of tablets (each $50 \mathrm{mg}$ LOS potassium), that will crushed and dissolved in distilled water.

\section{II-Stem cells (SCs)}

Allogenic PKH26 labeled rat bone marrow SCs were purchased from stem cell research unit at the Biochemistry Department, Faculty of Medicine, Cairo University.

\section{III-Animals}

Thirty-nine adult male albino rats with an average weight of $200 \mathrm{~g}$ were housed in Kasr Al Aini Animal house Faculty of Medicine, Cairo University and treated in accordance with guidelines approved by Animal use committee of Cairo University. All animals were kept under the same environmental conditions with free access to food and water.

\section{IV- Experimental design}

The rats were divided into four groups: Group I (Control group): 9 rats were subdivided into 3 subgroups, 3 rats for each experimental group.

Subgroup Ia: 3 rats, each received $0.5 \mathrm{ml}$ distilled water by IP as a single dose.

Subgroup Ib: 3 rats, each received a single IP injection of $0.5 \mathrm{ml}$ distilled water and after 3 weeks received $0.5 \mathrm{ml}$ distilled water orally for 3 weeks.

Subgroup Ic: 3 rats, each received a single dose of 0.5 $\mathrm{ml}$ distilled water IP and after 3 weeks they were injected with $0.5 \mathrm{ml}$ of PBS IV in the tail vein for two successive days.

Group II (DOX group): 10 rats, given DOX in a dose of $5 \mathrm{mg} / \mathrm{kg} \mathrm{IP}{ }^{[6 \& 7]}$ as a single dose. Each rat received $0.5 \mathrm{ml}$ distilled water containing $1 \mathrm{mg}$ DOX.

Group III (LOS group): 10 rats, each received DOX as in group II and after 3 weeks LOS $30 \mathrm{mg} / \mathrm{kg} /$ day $^{[8]}$ was administered orally for 3 weeks ${ }^{[7]}$ by the oral route through gastric tube ${ }^{[9]}$. Each rat received $0.5 \mathrm{ml}$ distilled water containing $6 \mathrm{mg}$ LOS.

Group IV (SC group): 10 rats, each received DOX as in group II and after 3 weeks each rat received $\mathrm{ml}$ of PKH26 labeled MSC suspension in BPS (3x106 cells $/ \mathrm{ml})$ for two successive days ${ }^{[10]}$ through the tail vein ${ }^{[1]}$.

\section{Preparation of the stem cells}

A. Isolation and Propagation in culture ${ }^{[12 \& 13]}$

B. Morphological identification of BM- derived $\mathrm{MSCS}^{[14]}$.

C. Labeling of stem cells with PKH26 dye $\mathrm{e}^{[15]}$.

D. Detection of homing of injected cells in the cardiac muscle of rat

\section{A-Biochemical study}

Before scarification blood samples were drawn from tail veins of all rats and collected in heparinized capillary tubes. Samples were analyzed for creatine kinase -MB (CK -MB), a marker of cardiac muscle damage ${ }^{[16]}$ at the Biochemistry Department, Faculty of Medicine, Cairo University.

\section{B-Histological study}

Scarification was done by $100 \mathrm{mg} / \mathrm{kg}$ ketaminexylazine IP ${ }^{[17]}$. Ventral middle incision was made, and the heart was extracted and washed in saline. Cardiac muscle specimens were obtained from the ventricles and the apex of the heart. They were fixed in $10 \%$ formol saline for 48 hours. Paraffin sections were cut at $5 \mu \mathrm{m}$ thickness and exposed to the following:

1. Haematoxylin and Eosin $(\mathrm{Hx} \& \mathrm{E}) \operatorname{stain}^{[18]}$

2. Masson's trichrome stain ${ }^{[19 \& 20]}$

3. Fluorescence detection (labeled MSC): fluorescent microscope was used to detect the injected SC labeled with a PKH26 dye ${ }^{[15]}$.

\section{C-Immunohistochemial Study}

\section{Connexin 43 (Cx43) Antibody}

It is a major component of gap junctions showing clear and specific labeling of intercalated discs ${ }^{[21]}$. It was obtained from (Santa Cruz Biotechnology, Inc, Europe $(\mathrm{C}-20) \mathrm{sc} 6560 \mathrm{Ab})$

\section{CD44 Antibody}

It is the marker for MSCs ${ }^{[22 \& 23]}$. It was obtained from (IHC world corporation, catalogue no IW-PA1021)

\section{D-Morphometric study}

Data were obtained using "Leica Qwin $500 \mathrm{C}$ " image analyzer computer system Ltd. (Cambridge, England). For each group, five slides of five different specimens were examined. From each slide, ten non-overlapping fields were measured in a standard measuring frame. The following parameters were measured:

1. Mean area percent of collagen fibers Masson's trichrome stained sections x 100

2. Mean area percent of $\mathrm{Cx} 43$ positive reaction $\mathrm{x} 100$ 
3. Mean number of CD44 positive immunostained cells x 400

\section{E-Statistical Analysis}

The measurements obtained were analyzed using SPSS software version 16 (SPSS, Chicago, IL). Comparison between different groups was made using analysis of variance (ANOVA) followed by post hoc Tukey test. The results were expressed as means \pm standard deviation (SD). The differences were considered statistically significant when " $p$ value" was $<0.05^{[24]}$.

\section{RESULTS}

\section{I-General Observation}

No deaths were observed the rats during the experiment.

\section{II-Biochemical Results}

Marked affection of cardiac injury characterized by a significant increase of serum CK-MB in all experimental groups. Mean value of CK-MB in the group I was $123.14+0.68$, while in group II was $298.16+6.57$. In group III was $189.58+6.86$ and group IV was $128.12+4.82$.

\section{III-Histological results}

\section{1) $H \& E$ stain (Plate1)}

Examination of sections of rat cardiac muscle of the group I showed elongated branching cardiac cells with cross striations exhibited rounded vesicular centrally located nuclei

Group II showed rarified widely separated muscle fibers. Many sections showed attenuated muscle fibers with wide endomysium. Focal areas of cytoplasm of different muscle fibers appeared either deeply acidophilic or vacuolated in others. Darkly stained pyknotic nuclei appeared peripheral in some fibers and lost in others. Thickened dilated congested blood vessels were seen, as well as areas of blood extravasation. There was localized large homogenous material with lost striation (infarction).

Group III showed many well-organized muscle fibers with central vesicular nuclei, while some fields showed few muscle fibers with peripheral dark nuclei and slightly rarified cytoplasm. There were many dilated congested blood vessels present between muscle fibers as well as many areas of blood extravasation.

Group IV showed well organized branched muscle fibers separated by fine endomysium and possessed vesicular centrally located nuclei. Some fibers possessed dark central nuclei surrounded by a halo. There was minimal cellular infiltration.

\section{2) Masson's Trichrome stain (plate 2)}

Examination of sections of cardiac muscle from the group I showed fine collagen fibers between the muscle fibers. Group II demonstrated dense collagen fibers between the muscle fibers and around blood vessels. Group III revealed few dense collagen fibers between cardiac muscle fibers. While Group IV showed minimal collagen fiber between cardiac muscle fibers as well as around multiple dilated blood vessels.

\section{2) Fluorescent Microscopic Results}

Sections of control, DOX and LOS groups showed absence of PKH26 labeled stem cells while sections of cardiac muscle in SC group showed the presence of PKH26 labeled stem cells among muscle fibers (Plate 3).

\section{IV-Immunohistochemical Results}

\section{Cx43 immunohistochemical stained sections (Plate 4)}

Examination of sections of cardiac muscle from the group I showed multiple immunostained positive $\mathrm{Cx} 43$ at intercalated discs. Group II showed few immunostained positive $\mathrm{Cx} 43$ at intercalated discs in the disrupted muscle fiber, sections of cardiac muscle from group III showed some immunostained positive $\mathrm{Cx} 43$ at intercalated discs. While the group IV showed multiple immunostained positive $\mathrm{Cx} 43$ at intercalated discs between the cardiomyocytes.

\section{CD44 immunohistochemical stained sections (Plate 5)}

Examination of sections of cardiac muscle from the group I showed positive immunostaining reactions at the endothelial lining of blood vessels. Group II positive CD44 endothelial cells of blood vessels and among cardiac muscle were observed. Sections of cardiac muscle in group III contained multiple positive CD44 endothelial cells of blood vessels and between the muscle fibers. On the other hand, sections in the cardiac muscle of rats in group IV revealed numerous positive cells among the muscle fibers and in vessels in multiple fields.

\section{V-Morphometric and Statistical Results}

\section{1) The mean values of serum CK-MB}

Statistical analysis revealed that the mean values of serum CK-MB showed a significant increase $(P \leq 0.05)$ in group II when compared to all other groups. It was a significant increase $(P \leq 0.05)$ in group III when compared to both groups I and IV. However, in group IV CK-MB level was significantly decrease $(P \leq 0.05)$ comparable to groups II and III with non-significant difference when compared to group I (Histogram 1).

\section{2) Mean area \% of collagen fibers (Table 1)}

The mean area $\%$ of collagen in Masson stained sections of group II indicated a significant increase $(P \leq 0.05)$ compared to all other groups. In the group III, there was significant decrease $(P \leq 0.05)$ in mean area\% of collagen fibers when compared to group II with non-significant difference versus the group IV. In group IV, there was significant decrease $(P \leq 0.05)$ in mean area\% of collagen fibers when compared to group II and non-significant difference when compared to the group I (Histogram 2) 


\section{3) Mean area \% of Cx43 immunohistochemical stain (Table 1)}

Regarding the mean area \% of $\mathrm{Cx} 43$ immunoexpression showed a significant decrease $(P \leq 0.05)$ in both groups II \&III when compared the control group. However, group IV showed a significant increase $(P \leq 0.05)$ in $\mathrm{Cx} 43$ immunostaining area \% when compared to both groups II\& III, but there was a non-significant difference versus the control group (Histogram 3)

\section{4) Mean number of CD44 immunopositive cells (Table 1)}

The mean number of CD44 positive cells in both groups III \& IV was significantly increased $(P \leq 0.05)$ when compared to group II. While group IV showed a significant increase $(P \leq 0.05)$ in positive CD44 cells when compared to group III (Histogram 4)

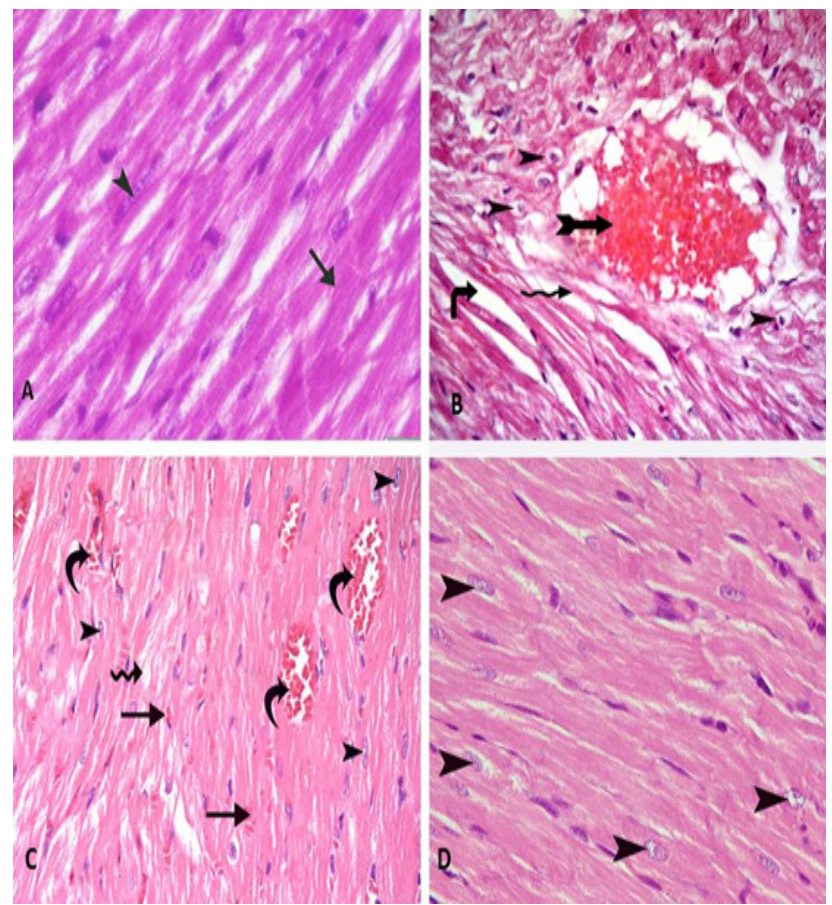

Plate 1: (A) Photomicrograph of the cardiac muscle from Group I) showing branched fibers (arrow) with cross striation and centrally located vesicular nuclei (arrow head). (B) Group II showing dilated congested blood vessel (bifid arrow), attenuated muscle fibers (spiral arrow) and some fibers show pyknotic nuclei surrounded by cytoplasmic halos (arrow heads). Note the presence of wide endomysium (right angled arrow). (C)Group III showing many well organized muscle fibers with central vesicular nuclei (arrow head), while some fibers show slightly rarified cytoplasm (spiral arrow). There are many dilated congested blood vessels present between muscle fibers (curved arrow), as well as many areas of blood extravasation (arrow) can also be seen.(D) Group IV showing apparently normal cardiac muscle fibers with central vesicular nuclei (arrow heads) (Hx\&E,x 400).

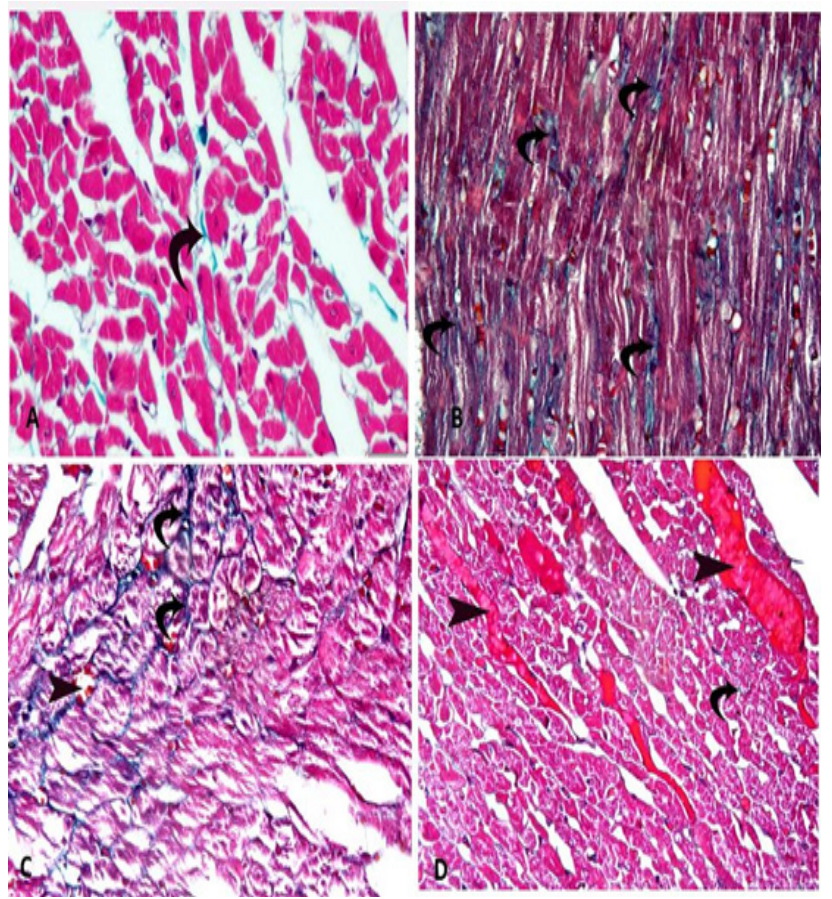

Plate 2: (A) Photomicrograph in the cardiac muscle of a rat in group I showing fine collagen fibers between the muscle fibers (curved arrow) B)Group II showing dense collagen fibers between the muscle fibers (curved arrows).(C) Group III showing few dense collagen fibers between cardiac muscle fibers (curved arrows), and around the dilated blood vessels (arrow head).(D) Group IV showing fine collagen fibers between the muscle fibers (curved arrow). There are also multiple dilated congested blood vessels (arrow heads) (Masson's trichrome, x 400)

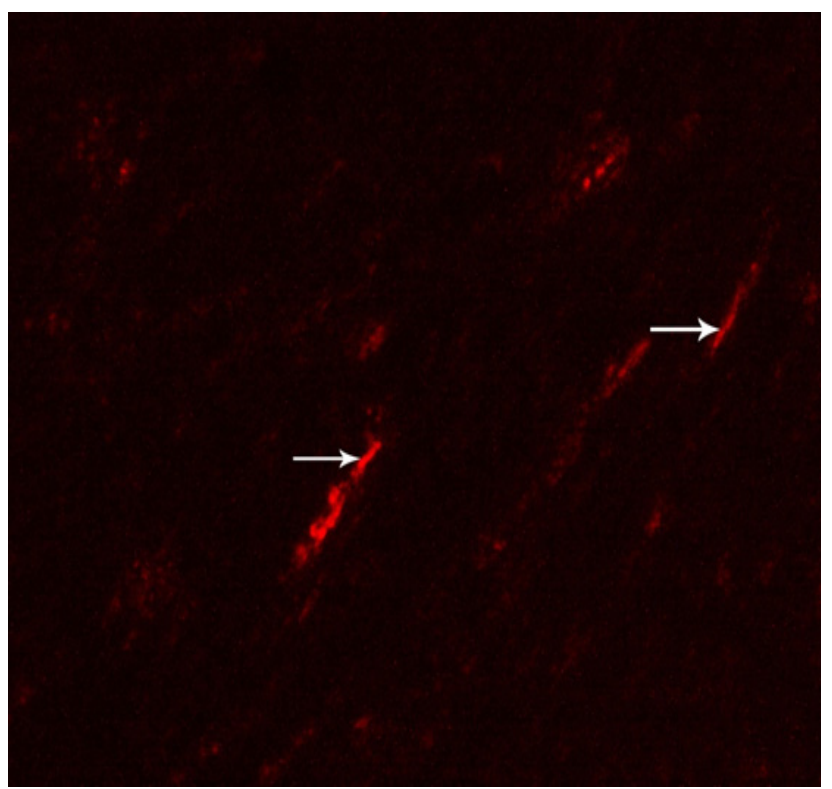

Plate 3: Photomicrograph of a section in the cardiac muscle of a rat from group IV showing few fluorescent labeled cells among the fibers (thin arrows) (PKH26, x 100). 


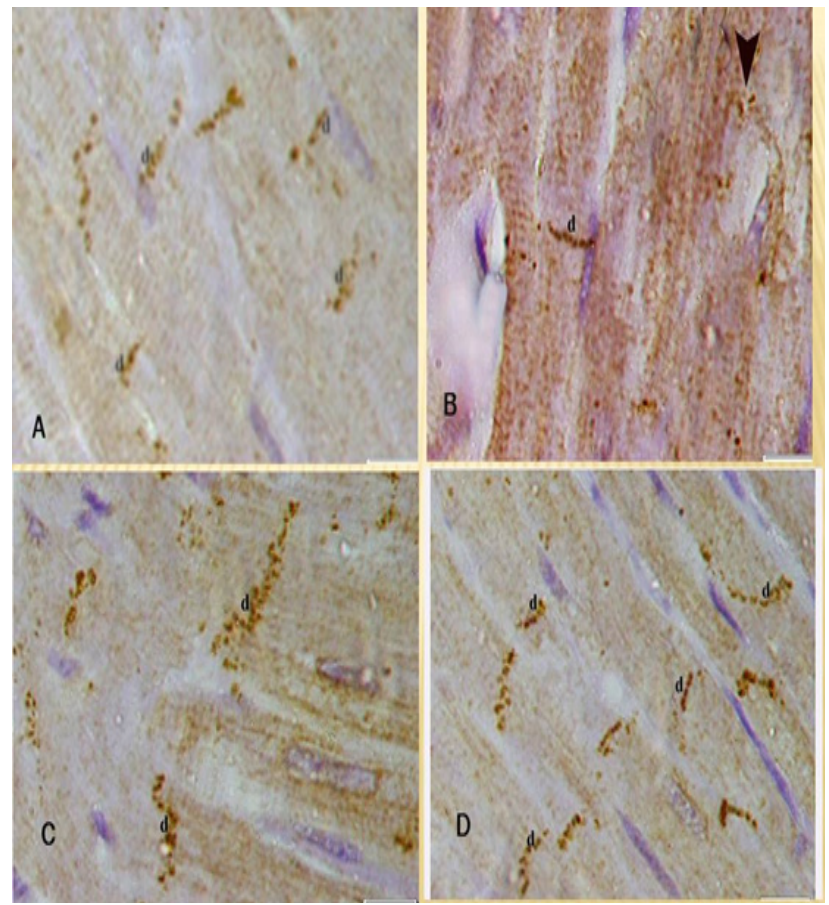

Plate 4: (A)Photomicrograph of a section in the cardiac muscle of a rat from group I showing multiple $\mathrm{Cx} 43+$ ve intercalated discs between the cardiac myocytes (d).(B) Group II showing few Cx43 +ve intercalated discs (d), while many cardiac muscle fibers show disrupted intercalated discs(arrow head).(C)Group III showing some $\mathrm{Cx} 43$ +ve intercalated discs (d) between the cardiac myocytes.(D) Group IV showing multiple $\mathrm{Cx} 43$ +ve intercalated discs (d) between the cardiac myocytes (Cx 43 immunostaining, $x 1000$ ).

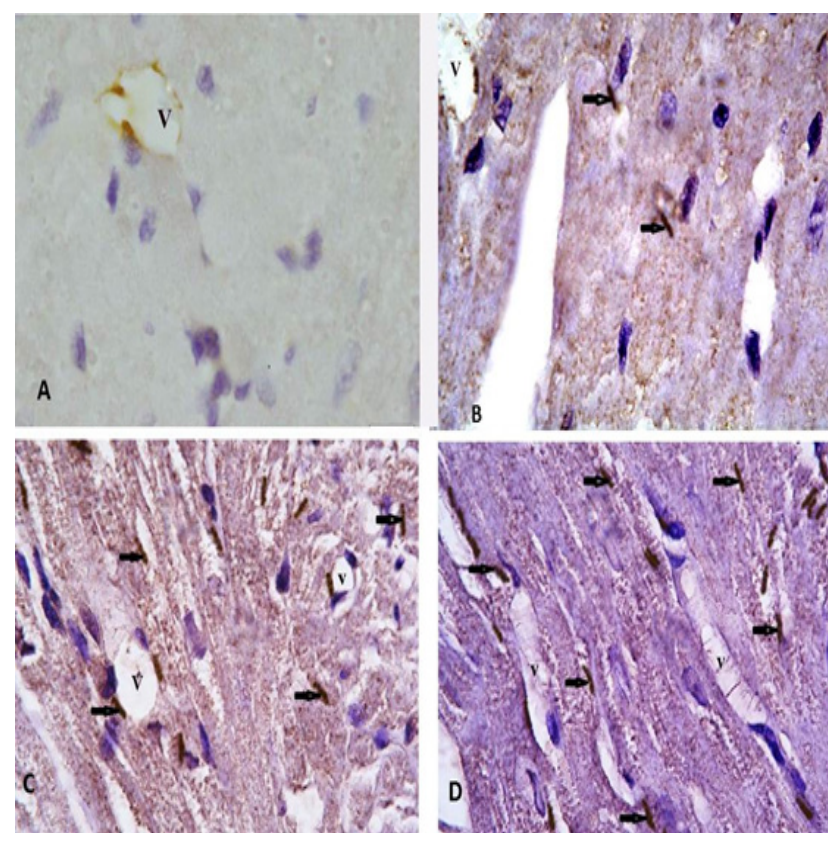

Plate 5: (A) Photomicrograph of a section in the cardiac muscle of a rat from group I showing few +ve cells at the endothelial cells lining of blood vessels (v) .(B) Group II showing few +ve cells (arrows) among the muscle fibers and in the endothelial cells lining the blood vessels (v).(C) Group III showing multiple + ve immunostaining cells (arrows) among the fibers and in the endothelial cells lining blood vessel (v). (D) Group IV showing numerous + ve immunostaining cells (arrows) among the fibers, and in endothelial cells lining blood vessel (v) (CD44 immunostaining, $\mathrm{x} 1000$ ).

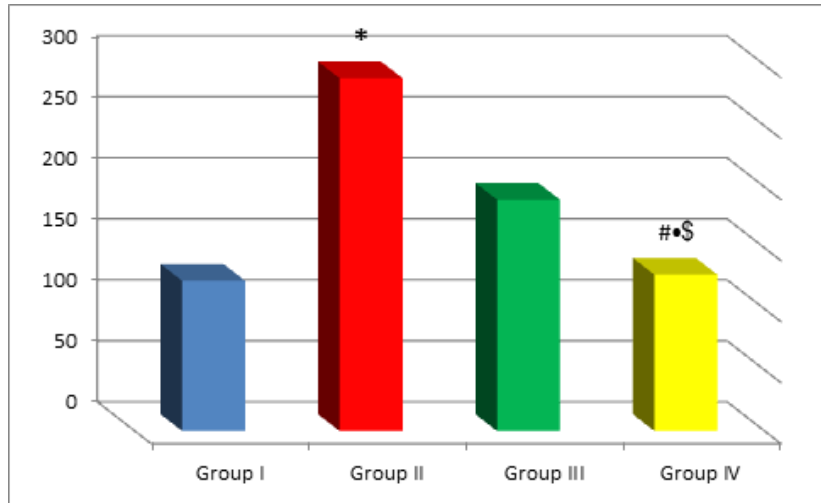

Histogram 1: Mean values of serum CK-MB in all studied groups

* Significant $(P \leq 0.05)$ compared to group I

- Significant $(P \leq 0.05)$ compared to group II

\# Significant $(P \leq 0.05)$ compared to group III

O Significant $(P \leq 0.05)$ compared to group IV

$\$$ Non-significant difference when compared to a group I

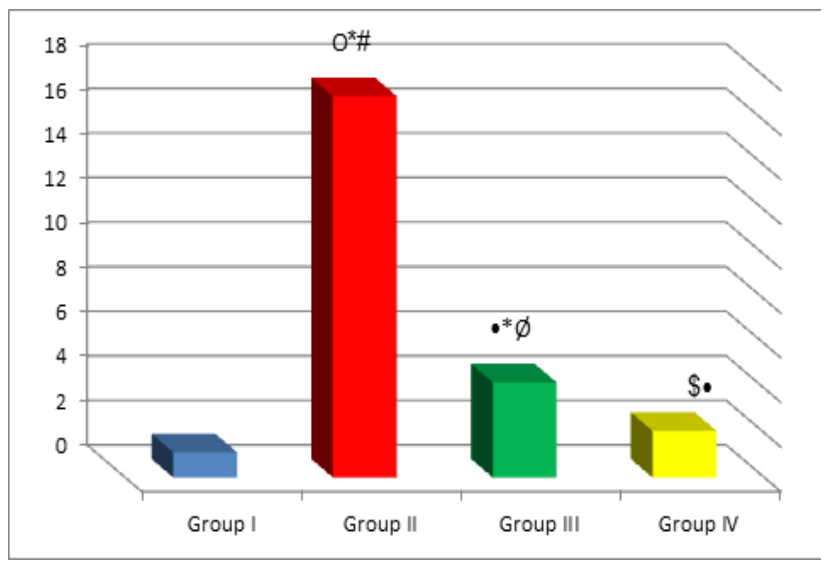

Histogram 2: Mean area \% of collagen fibers in all studied groups * significant $(P \leq 0.05)$ compared to group I

- Significant $(P \leq 0.05)$ compared to group II

\# Significant $(P \leq 0.05)$ compared to group III

O Significant $(P \leq 0.05)$ compared to group IV

$\varnothing$ Non-Significant $(P \leq 0.05)$ compared to group IV

$\$$ Non-significant difference when compared to the group I

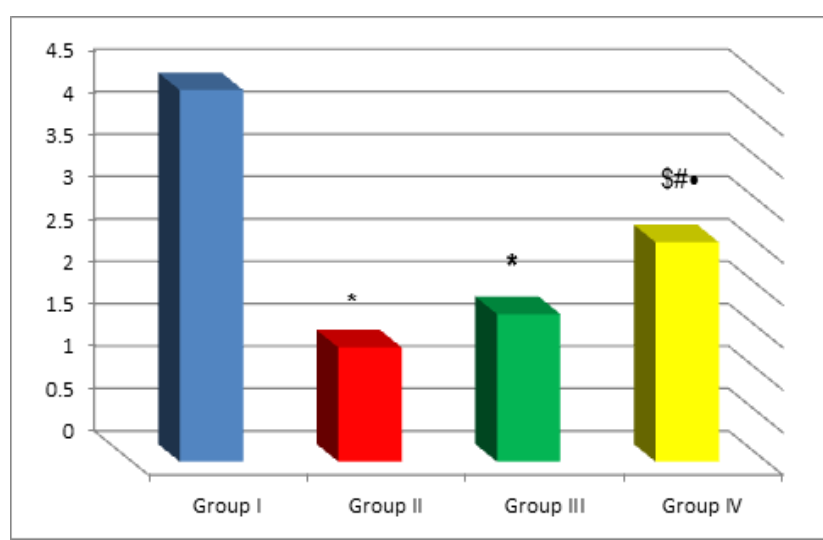

Histogram 3: Mean area \% of Cx43 immunostaining

*significant $(P \leq 0.05)$ compared to group I

- Significant $(P \leq 0.05)$ compared to group II

\# Significant $(P \leq 0.05)$ compared to group III

$\$$ Non-significant difference when compared to the group I 


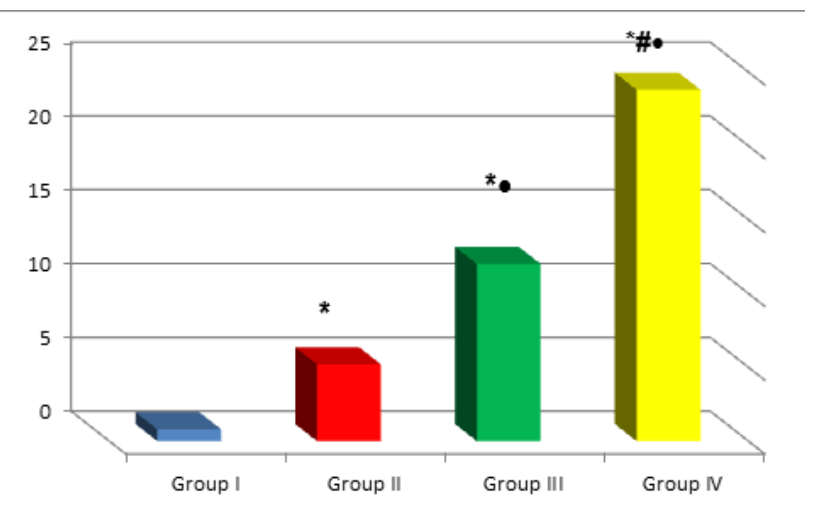

Histogram 4: Mean number of CD44 immunopostive cells *significant $(P \leq 0.05)$ compared to group I

- Significant $(P \leq 0.05)$ compared to group II

\# Significant $(P \leq 0.05)$ compared to group III

Table 1: Mean area \% of collagen fibers, mean area $\%$ of $\mathrm{Cx} 43$ immunostainning and mean number of CD44 positive cells

\begin{tabular}{lccc}
\hline Groups & $\begin{array}{c}\text { Mean area \% of } \\
\text { collagen fibers }\end{array}$ & $\begin{array}{c}\text { Mean area } \\
\% \text { Cx43 } \\
\text { immunoreactivity }\end{array}$ & $\begin{array}{c}\text { Mean number } \\
\text { of CD44 } \\
\text { immunostained } \\
\text { cells }\end{array}$ \\
\hline $\begin{array}{l}\text { Control group } \\
\text { Group II (DOX } \\
\text { group): }\end{array}$ & $17.1340 \pm 0.46$ & $4.380 \pm 1.762$ & $0.8 \pm 0.44$ \\
$\begin{array}{l}\text { Group III } \\
\text { (Losartan }\end{array}$ & $4.266 \pm 2.41^{* * \varnothing}$ & $1.740 \pm 0.291^{*}$ & $12 \pm 1.58^{* *}$ \\
$\begin{array}{l}\text { group): } \\
\begin{array}{l}\text { Group IV } \\
\text { (SC group): }\end{array}\end{array}$ & $2.094 \pm 1.6^{* \$}$ & $2.589 \pm 1.66^{* * \$}$ & $23.8 \pm 3.1^{* * \#}$ \\
\hline
\end{tabular}

* Significant $(P \leq 0.05)$ compared to group I

- Significant $(P \leq 0.05)$ compared to group II

\# Significant $(P \leq 0.05)$ compared to group III

O Significant $(P \leq 0.05)$ compared to group IV

\$ Non-significant difference when compared to the group I

$\varnothing$ Non-Significant $(P \leq 0.05)$ compared to group IV

\section{DISCUSSION}

Cardiovascular disease is the leading cause of mortality and morbidity worldwide ${ }^{[25]}$.

Many pharmacological agents may acutely lesion the myocardium either causing myocarditis or a chronic lesion like dilated idiopathic cardiomyopathy. Among these agents, we point out $\mathrm{DOX}^{[26]}$.

The current study was designed to evaluate and compare the possible therapeutic and regenerative effect of both MSCs and LOS on experimentally induced cardiotoxicity using DOX in male albino rats. Biochemical, histological and immnunohistochemical techniques in addition to morphological measurements and statistical analysis of data were done.

In the present study, analysis of serum CK-MB revealed a significant increase in the 0 mean values of DOX group when compared to all groups. This is in consistent with previous reports where DOX- induced cardiotoxicity characterized by an elevation of $\mathrm{CK}-\mathrm{MB}^{[27]}$. There was a significant increase in group III when compared to I and IV group. This could be explained by the study of ${ }^{[28]}$ that the ameliorating effect of SCs over that produced by LOS and also documented that LOS neither stimulated nor prevented cardiomyocyte regeneration.

There was significant decrease in group IV when compared to groups II and III and non-significant difference when compared to group I. ${ }^{[29]}$ speculated that MSCs secret certain cytokines, thus promote myocardial glucose metabolism, stimulate cardiomyocytes regeneration and enhance cardiac function.

By LM examination, cardiomyopathic findings were in the form of fragmentation with loss transverse striations of muscle fibers. Many sections showed attenuated muscle fibers with wide endomysium. Some muscle fibers showed focal areas of deep cytoplasm staining indicating cytoplasmic protein denaturation ${ }^{[30]}$ As well as, other fibers showed vacuolated cytoplasm that might be related myofibril loss or vacuolar degeneration caused by intracellular water and electrolytes redistribution ${ }^{[31]}$. It was associated with multiple pyknotic nuclei might be due to myocardial apoptosis, some of which were eccentric might be due to peripheral chromatin condensation. These changes were recorded by ${ }^{[32]}$. A number of studies have suggested that apoptosis is associated with oxidative stress $^{[33]}$.

The present study revealed congested blood vessels and wide areas of extravasated RBCs among the muscle fibers in group II. Congestion of the vessel might be due to weakness of the vessel's walls as a result of inflammation with consequent damage of the vessel wall and interstitial hemorrhage ${ }^{[34]}$. This is in agreement with ${ }^{[35]}$ who reported focal hyalinization of myocardial bundles with focal hemorrhages in-between the cardiac fibers.

Homogenous material was noticed among the fibers, diffuse interstitial oedema and pale myocytes with fading nuceli indicating the coagulative necrosis (infarction) this finding was in agreement with ${ }^{[36]}$. This could be explained by the immediate effect of DOX on the morphology of the regional vasculature manifested by disintegration of the vessel's wall and activation of coagulation and platelet aggregation pathways and microthrombi formation, leading to acute reduction in vascular blood flow and could be followed by infarction as was recorded ${ }^{[37]}$.

In the LOS group showed many well-organized muscle fibers with central vesicular nuclei this explained by ${ }^{[38]}$ that LOS could inhibit the oxidative stress via upregulation of NO synthase enzyme.

As regards dilated congested blood vessels ${ }^{[39]}$, reported that LOS induced a stimulation of angiogenesis via inhibitory function of Ang II on the AT1 receptor. But ${ }^{[40]}$, stated that the exact role of LOS in angiogenesis has been contradictory. 
In the current work, homing of MSCs was confirmed by the fluorescent microscope which exhibited some PKH26 labeled cells among the fibers. And this is in agreement with $^{[41]}$.

Section from SC group revealed apparently normal arrangement that well-organized cardiac muscle. Transplanted MSCs have ability to differentiate into cardiomyocytes and vasculature. This could be explained by ${ }^{[42]}$. Mesenchymal stem cells injection promotes the cardiac progenitor cells (CPCs) and helps in the improvement of myocardium as CPCs could develop into the three main types of adult heart cells; cardiomyocytes, endothelial cells and smooth muscle cells that are required for heart regeneration ${ }^{[43]}$.

It was reported that MSCs secrete a wide array of paracrine factors which led to immunosuppressive, antifibrotic, pro-angiogenic, and anti-oxative responses ${ }^{[44]}$.

Examination of Masson's trichrome stained sections of cardiac muscle from group II demonstrated dense collagen fibers between the muscle fibers and around blood vessels. This is in accordance with ${ }^{[45]}$ who explained that fibrosis was due to excessive cardiac fibroblast accumulation and extracellular matrix deposition .Moreover, DOX increase expression of tumor necrosis factor-beta (TGF- $\beta)^{[46]}$ reported that the TGF- $\beta$ is a strong stimulator of pathological collagen production as well as a cytokine that has been associated to fibro-inflammatory signaling.

Group III revealed few dense collagen fibers between cardiac muscle fibers ${ }^{[47]}$ mentioned that LOS is an antifibrotic agent; it directly antagonizes TGF- $\beta$ via AT1. While group IV showed minimal collagen fiber between cardiac muscle fibers this could be via paracrine signaling from MSCs mediated by anti-fibrotic factors. In addition, the cultured MSCs express hepatocyte growth factor that has been shown to exert antifibrotic, antiapoptotic and angiogenic effects that may participate in amelioration of cardiac fibrosis ${ }^{[48]}$.

The expression of $\mathrm{Cx} 43$ in the heart muscle is critical for synchronized contraction between cardiomyocytes ${ }^{[49]}$ and it is an important molecule in the regenerative healing of heart ${ }^{[50]}$.

In group II showed few $\mathrm{Cx} 43$ positive reaction at intercalated discs in the disrupted muscle fiber, this was confirmed by the morphometric results where there was a significant decrease mean area \% of immunoreactivity, which reflects gradual decrease in percentage of healthy cardiac muscle fibers in group II when compared to the control group. These results are in agreement with $^{[51]}$ who explained that DOX treatment induced slower proliferation rates, decreased $\mathrm{Cx} 43$ production and hindered SC capacity to respond to cardiomyogenic differentiation stimuli.

Group III showed some $\mathrm{Cx} 43$ positive reaction between the myocyte. The mean area $\%$ of $\mathrm{Cx} 43$ immunoractivity in this group showed a significant decrease when compared to the control group; this might be due to decreased production of $\mathrm{Cx} 43$. It was reported that upregulation of $\mathrm{Cx} 43$ protein in response to Ang II and also stated that LOS reduced the over-expressions of $\mathrm{Cx} 43$ in the myocardium $^{[52]}$.

Group IV showed multiple Cx43 positive reaction at intercalated discs between the cardiomyocyte. There was a significant increase in the mean area \% of $\mathrm{Cx} 43$ immunoexpression, which reflect increase in percentage of healthy cardiac muscle fibers when compared to both groups II and III, and a non-significant difference versus the control group. MSCs have been documented to modulate conduction of cardiomyocytes by increase in the conduction velocity of cardiomyocyte by paracrine signaling, via upregulation of $\mathrm{Cx} 43$ and nerve growth factor $^{[53]}$.

In group II sections of cardiac muscle stained with CD44 immunohistochemical stain showed few positive spindle cells confined to the endothelial cells in the blood vessels walls and among the muscle fibers. The mean number of CD44 positive cells was a significant decrease in group II when compared to all groups. This could be explained by ${ }^{[54]}$ who demonstrated that hypoxia improves MSC self-renewal and therapeutics resulted in SCs migration, increased cell adhesion and activation of target genes coding for paracrine factors, which accelerate tissue regeneration.

As regards the group III, sections of cardiac muscle revealed multiple CD44 positive cells among the fibers and the endothelial cells of blood vessels. The mean number of CD44 positive cells in group III was significantly increased when compared to the group II, but significantly decreased when compared to IV group as angiotensin receptor blockers improved the efficiency of cardiomyogenic transdifferentiation and improved the cardiac function via neovascularization that restored the contractility ${ }^{[55]}$.

Sections from group IV displayed multiple CD 44 positive cells among the muscle fibers and in endothelial cells of blood vessels. The mean number of CD44 positive cells in group IV were significantly increased when compared to both group II\&III. This could be explained by ${ }^{[56]}$ who that BM-MSCs could express important SCs surface markers such as CD44, CD90 and CD105. In addition $^{[57]}$, stated that CD44 is a cell adhesion receptor and is involved in cell-cell interactions, cell adhesion and migration. The improved CD34 and CD44 expression reflects a recovery in bone marrow function ${ }^{[58]}$.

\section{CONFLICT OF INTEREST}

There are no conflicts of interest.

\section{REFERENCES}

1. Mozaffarian D, Benjamin EJ, Go AS, Arnett DK, Blaha MJ, et al. Heart disease and stroke statistics--2015 update: a report from the: a report from the American Heart Association.Circulation, 2015; 31(4):e29-322. 
2. Ojha S, AlTaee H, Goyal S, Mahajan UB, Patil CR2 et al. Cardioprotective Potentials of Plant-Derived Small Molecules against Doxorubicin Associated Cardiotoxicity. Oxid Med Cell Longev. 2016; 2016:5724973.

3. Kobayashi M, Ota S, Terada S, Kawakami Y, Otsuka $\mathrm{T}$ et al. The Combined Use of Losartan and MuscleDerived Stem Cells Significantly Improves the Functional Recovery of Muscle in a Young Mouse Model of Contusion Injuries. Am J Sports Med. 2016; 44(12):3252-3261.

4. Singh A, Singh A, Sen D. Mesenchymal stem cells in cardiac regeneration: a detailed progress report of the last 6 years (2010-2015).Stem Cell Res Ther, 2016; 7 (1):82.

5. Abd Allah SH, Hussein S, Hasan MM, Deraz RHA, Hussein WF et al. Functional and structural assessment of the effect of human umbilical cord blood mesenchymal stem cells in doxorubicin-induced cardiotoxicity. J Cell Biochem. 2017; 118(10): 3119-3121.

6. Arola OJ, Saraste A, Pulkki K, Kallajoki M, Parvinen $\mathrm{M}$ et al. Acute doxorubicin cardiotoxicity involves cardiomyocyte apoptosis. Cancer Res.2000; 60(7):1789-1792.

7. Zhu J, Zhang J, Xiang D, Zhang Z, Zhang L et al. Recombinant human interleukin-1 receptor antagonist protects mice against acute doxorubicin-induced cardiotoxicity. Eur J Pharmacol, 2010; 643, (2): 247-253.

8. Bishu K, Ogut O, Kushwaha S, Mohammed SF, Ohtani $\mathrm{T}$ et al. Anti-remodeling effects of rapamycin in experimental heart failure: dose response and interaction with angiotensin receptor blockade PLoS One. 2013; 8(12):e81325.

9. Elewa. Study the Nephro-protective Effects of Losartan on Rats. Elewal, Int J Clin Pharmacol Pharmacother, 2016; 1:(101) 1-4

10. Isik AT, Celik T, Ural AU, Tosun M, Ulusoy G et al. Mesenchymal stem cell therapy for the streptozotocininduced neurodegeneration in rats. Neurol Res,2016; 38(4): 364-372.

11. Lee Y, Hwang J, Park S, Shin I, Kang S et al. Reduction of liver fibrosis by xenogeneic human umbilical cord blood and adipose tissue-derived multipotent stem cells without treatment of an immunosuppressant. Tissue Engineering and Regenerative Medicine. 2008; 5 (4): 613-621.

12. Sassoli C, Nosi D, Tani A, Chellini F, Mazzanti B et al. Defining the role of mesenchymal stromal cells on the regulation of matrix metalloproteinases in skeletal muscle cells. Experimental Cell Research. 2014; 323: 297-313.
13. Espina M, Jülke H, Brehm W, Ribitsch I, Winter K et al. Evaluation of transport conditions for autologous bone marrow-derived mesenchymal stromal cells for therapeutic application in horses. PeerJ 2016; 4: e1773-1795

14. Bivalacqua TJ, Deng W, Kendirci M, Usta MF, Robinson $\mathrm{C}$ et al. Mesenchymal stem cells alone or ex vivo gene modified with endothelial nitric oxide synthase reverse age-associated erectile dysfunction. Am J Physiol Heart Circ Physiol.2007 ; 292(3):H12781290.

15. Ude CC, Shamsul BS, Ng MH, Chen HC, Norhamdan MY et al. Bone marrow and adipose stem cells can be tracked with PKH26 until post staining passage 6 in in vitro and in vivo. Tissue and Cell. 2012; 44: 156-163.

16. Radhiga T, Rajamanickam C, Senthil S, Pugalendi $\mathrm{KV}$. Effect of ursolic acid on cardiac marker enzymes, lipid profile and macroscopic enzyme mapping assay in isoproterenol- induced myocardial ischemic rats. Food Chem Toxicol .2012 ; 50(11): 3971-3977.

17. Wellington D, Mikaelian I, Singer L. Comparison of ketamine-xylazine and ketamine-dexmedetomidine anesthesia and intraperitoneal tolerance in rats. J Am Assoc Lab Anim Sci. 2013; 52(4):481-7.

18. Kiernan JA. Histological and histochemical methods: Theory and Practice. $3^{\text {rd }}$ ed., Arnold publisher, London, New York \& New Delhi:2001 ; 111-162.

19. Bancroft J D \& Gamble M. Theory and practice of histological techniques, 5 edition, Churchill Livingstone, New York, London. 2008; 150

20. Suvarna SK, Layton C, Bancroft JD. Connective and mesenchymal tissue with their stains. In: Bancroft's Theory and practice of histological techniques, 7 th ed., Elsevier Health Sciences, Churchill Livingstone.2012; 187-214.

21. Hutchings G, Gevaert T, Deprest J, Roskams T, Van Lommel et al. Immunohistochemistry using an antibody to unphosphorylated connexin 43 to identify human myometrial interstitial cells. Reprod Biol Endocrinol.2008; 6:43.

22. Noorden S. Principles of immunostaining. In: Histochemistry in Pathology. Churchill Livingstone, Edinburgh. 1990; 31.

23. Chen $\mathrm{C}$, Huang $\mathrm{H}$, Louis $\mathrm{C}$, Lin $\mathrm{K}$, Ron Y. Isolation of multilineage progenitors from mouse brain. In Vitro Cell Dev Biol Anim. 2013; 49(5): 307-314.

24. EmsleyR, Dunn G, White IR.Mediation and moderation of treatment effects in randomized controlled trials of complex interventions. Stat Methods Med Res. 2010; 19(3): 237-270

25. Karantalis V \& Hare JM (2015): Use of mesenchymal stem cells for therapy of cardiac disease. Circ Res. 2015; 116(8):1413-1430 
26. Pontes JC, Gomes Júnior JF, Silva GV, Benfatti RA, Dias AE et al. Anatomopathological study of cardiomyopathy induced by doxorubicin in rats.Acta Cir Bras.2010;25(2):137-43

27. Arafa MH, Mohammad NS, Atteia HH, AbdElaziz HR. Protective effect of resveratrol against doxorubicin-induced cardiac toxicity and fibrosis in male experimental rats. J Physiol Biochem.2014; 70: 701-711.

28. Segersvärd H, Lakkisto $\mathrm{P}$, Forsten $\mathrm{H}$, Immonen $\mathrm{K}$, Kosonen R (2015): Effects of angiotensin II blockade on cardiomyocyte regeneration after myocardial infarction in rats.J Renin Angiotensin Aldosterone Syst.2015; 16(1):92-102

29. Abdel Hamid KM, Abdel Mola AF, Meligy FY, Abd Allah ESH. The Possible Protective Role OF Ginger Extract Versus Vitamin E Against Simvastain Induced keletal Myotoxicity in Adult Male Albino Rat:Histological, Physiological and Biochemical Study. The Egyptian Journal of Histology. 2017; 40:156-168.

30. Cai M, Shen R, Song L, Lu M, Wang J.Erratum: Bone Marrow Mesenchymal Stem Cells (BMMSCs) Improve Heart Function in Swine Myocardial Infarction Model through Paracrine Effects. Sci Rep. 2016 ; 6:31528

31. Balli E, Mete UO, Tuli A, Tap O,Kaya M. Effect of melatonin on the cardiotoxicity of doxorubicin. Histol. Histopathol. 2004; 19(4):1101-1108.

32. Maiim MM. Potential protective effect of captopril against doxorubicin-induced cardiotoxicity in rats: Light and electron microscopic study. Suez Canal Univ. Med J.2005 ; 8(2):169-178

33. Octavia Y, Tocchetti CG, Gabrielson KL, Janssens S, Crijns HJ et al. Doxorubicin-induced cardiomyopathy: from molecular mechanisms to therapeutic strategies. J Mol Cell Cardiol.2012 ; 52(6):1213-1225

34. Lazzeri E, Angelotti ML, Ballerini L, Becherucci F, Mazzinghi B et al.The role of endothelial progenitor cells in renal disease. G Ital Nefrol.2008; 25(5): 537-546

35. Sharkey LC, Radin MJ, Heller L, Rogers LK, Tobias A et al.Differential cardiotoxicity in response to chronic doxorubicin treatment in male spontaneous hypertension-heart failure (SHHF), spontaneously hypertensive (SHR), and Wistar Kyoto (WKY) rats. Toxicol Appl Pharmacol.2013; 273: 47-57.

36. Ichikawa $\mathrm{Y}$, Ghanefar $\mathrm{M}$, Bayeva $\mathrm{M}, \mathrm{Wu} \mathrm{R}$, Khechaduri A et al. Cardiotoxicity of doxorubicin is mediated through mitochondrial iron accumulation. J Clin Invest.2014 ;124:617-630.

37. Ben Aharon I, Bar Joseph H, Tzabari M, Shenkman $\mathrm{B}$, Farzam $\mathrm{N}$ et al. Doxorubicin-induced vascular toxicity--targeting potential pathways may reduce procoagulant activity. PLoS One.2013 ; 8(9):e75157

38. Lee E, Kim DY, Kim AY, Lee EJ, Kim SH et al.Chronic effects of losartan on the muscles and the serologic profiles of mdx mice. Life Sci.2015; 143:35-42.

39. Walther T, Menrad A, Orzechowski HD, Siemeister $\mathrm{G}$, Paul $\mathrm{M}$ et al. Differential regulation of in vivo angiogenesis by angiotensin II receptors. FASEB J.2003; 17(14):2061

40. Willis LM1, El-Remessy AB, Somanath PR, Deremer DL, Fagan SC.Angiotensin receptor blockers and angiogenesis: clinical and experimental evidence. Clin Sci (Lond), 2011; 120(8):307-319.

41. Cao Z, Zhang G, Wang F, Liu H, Liu L et al. Protective effects of mesenchymal stem cells with CXCR4 upregulation in a rat renal transplantation model. PLoS ONE. 2013; 8(12): 82949-82961.

42. Wang Y, Chen X, Cao W, Shi Y. Plasticity of mesenchymal stem cells in immunomodulation: pathological and therapeutic implications. Nat Immunol. 2014; 15:1009-1016.

43. Wu JM, Hsueh YC, Ch'ang HJ, Luo CY, Wu LW et al. Circulating cells contribute to cardiomyocyte regeneration after injury. Circ Res.2015 ; 116 (4): $633-41$

44. Maria AT, Maumus M, Le Quellec A, Jorgensen C1, Noël D, et al. Adipose-Derived Mesenchymal Stem Cells in Autoimmune Disorders: State of the Art and Perspectives for Systemic Sclerosis. Clin Rev Allergy Immunol. 2017; 52(2):234-259.

45. Krenning G, Zeisberg EM and Kalluri R. The origin of fibroblasts and mechanism of cardiac fibrosis. J Cell Physiol. 2010; 225 (3):631-637.

46. Krstić J, Trivanović D, Mojsilović S, Santibanez JF (2015): Transforming growth factor-beta and oxidative stress interplay: implications in tumorigenesis and cancer progression. Oxid Med Cell Longev. 2015; 2015:654594.

47. Spurney CF, Sali A, Guerron AD, Iantorno M, Yu Q et al. Losartan decreases cardiac muscle fibrosis and improves cardiac function in dystrophin-deficient mdx mice. J Cardiovasc Pharmacol Ther.2011 ; 16(1): $87-95$.

48. Li L, Zhang Y, Li Y, Yu B, Xu Y et al. Mesenchymal stem cell transplantation attenuates cardiac fibrosis associated with isoproterenol-induced global heart failure. Transpl Int. 2008; (12):1181-1189.

49. Shibuya M, Miura T, Fukagawa Y, Akashi S, Oda T et al. Tongue Muscle-Derived Stem Cells Express Connexin 43 and Improve Cardiac Remodeling and Survival After Myocardial Infarction in Mice. Circ J.2010; 74:1219- 1226 
50. Ongstad EL, O'Quinn MP, Ghatnekar GS, Yost MJ, Gourdie RG.A Connexin43 Mimetic Peptide Promotes Regenerative Healing and Improves Mechanical Properties in Skin and Heart .Adv Wound Care (New Rochelle). 2013; 2(2):55-62.

51. Oliveira MS, Melo MB, Carvalho JL, Melo IM, Lavor MS, et al. Doxorubicin Cardiotoxicity and Cardiac Function Improvement after Stem Cell Therapy Diagnosed by Strain Echocardiography. J Cancer Sci Ther. 2013; 5(2):52-57.

52. Zhao LL, Chen HJ, Chen JZ, Yu M, Ni YLet al. Losartan reduced connexin43 expression in left ventricular myocardium of spontaneously hypertensive rats.J Zhejiang Univ Sci B. 2008; 9(6):448-54.

53. Chen T, Shen HM, Deng ZY, Yang ZZ, Zhao RL et al. A herbal formula, SYKT, reverses doxorubicin induced myelosuppression and cardiotoxicity by inhibiting ROS mediated apoptosis. Mol Med Rep.2017; 15(4):2057-2066.

54. Cerrada I, Ruiz-Saurí A, Carrero R, Trigueros C, Dorronsoro A. Hypoxia-inducible factor 1 alpha contributes to cardiac healing in mesenchymal stem cells-mediated cardiac repair. Stem Cells Dev.2013 22(3):501-11

55. Numasawa Y, Kimura T, Miyoshi S, Nishiyama N, Hida $\mathrm{N}$ et al. Treatment of human mesenchymal stem cells with angiotensin receptor blocker improved efficiency of cardiomyogenic transdifferentiation and improved cardiac function via angiogenesis. . Stem Cells.2011; 29(9):1405-1414.

56. Maleki M, Ghanbarvand F, Reza Behvarz M, Ejtemaei M, Ghadirkhomi E(2014): Comparison of mesenchymal stem cell markers in multiple human adult stem cellsInt J Stem Cells.2014 ; 7(2):118-26

57. Yan D, Liu X, Hua L, Wu K, Sha X et al. MMP-14 promotes VSMC migration via up-regulating CD44 expression in cardiac allograft vasculopathy. Pathol Res Pract.2016 ; 212(12):1119-1125

58. Chen T, Shen HM, Deng ZY, Yang ZZ, Zhao RL et al. An herbal formula, SYKT, reverses doxorubicin induced myelosuppression and cardiotoxicity by inhibiting ROS mediated apoptosis. Mol Med Rep.2017; 15(4):2057-2066 


\section{الملخص العربى}

\section{دراسة هستولوجية مقارنة بين تاثير الخلايا الجذعية المزنشيمية وعقار اللوسارتان

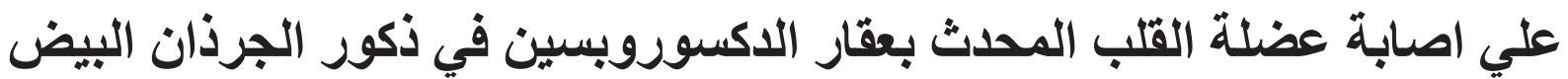

سمية سعد زغلول'، رحمة كمال الدين ابو النور '،مروة محمد عبد الفتاح' ، داليا ابراهيم اسماعيل' قسم الهستولوجي- كلية الطب- 'جامعة مصر للعلوم والتكنولوجيا ـ 'جامعة القاهرة_القاهرة-مصر

الخلقية: تعتبر أمر اض القلب والاوعية الدموية السبب الرئيسي للوفاة علي مستوي العالم. ويمكن للخلايا الجذعية المزنشمية ان تكون علاجا واعدا لعلاج اعتلال عضلة القلب. الهـف من العمل: لمقارنة التأثثر العلاجي للخلايا الجذعية المزنشيمية و اللوسارنان على اعتلال عضلة القلب المستحدث بعقار الدوكسوروبيسين.

$$
\text { مواد وطرق البحث: تم تقسيم تسعة وثلاثون من ذكور الجرذان البيض قسمت الي }
$$

المجمو عة الأولي كمجمو عة ضابطة، تلقت المجمو عة الثانية الدوكسوروبيسين ه ملج/كج داخل تجويف الغشاء البريتونى لمرة و احدة. وتلقت المجموعة الثالثة الدوكسوروبيسين كما في المجموعة الثانية وبعد ب أسابيع تم اعطائهم • ب ملج / كج / يو ميا اللوسارتان عن طريق انبوبة المعدة لمدة ثلاثة أسابيع. وكذلك تلقت جرذان المجموعة المجموعة الر ابعة PKH26 الدوكسوربيسين كما في المجموعة الثانية وبعد ثلاثة اسابيع تم حقهم بالخلايا الجذعية المزنشمية المميزة بـ عن طريق الوريد وتم تجميع عينات الدم لقياس قيمة CK-MB ثم فحص الثرائح عضلة القلب في كل المجمو عات بو اسطة المجهر الفلورنسي MB وتمت معالجة كل شرائح للار اسة الهستولوجية باستخدام صبغة الهيماتوكسيلين و الايوسين وماسون ثلاثية الألو ان بالاضافة الي الصبغة هستوكيميائية مناعية CD43 و CX44 كما تم اجر اء دراسة

$$
\text { مورفومترية و احصائية. }
$$

النتائج: اظهرت المجموعة الثانية الالياف العضلية مجزأة كما ظهرت فجوات في السيتوبلازم بالاضافة الي فقدان التخطيطية العرضية ولقد تاكدت هذة التغير ات بزيادة ذو دلالة احصائية في قيم CK-MB ومتوسط النسبة المئوية لمساحة الياف الكو لاجين مقارنة بكل المجمو عات الاخري ولقد لوحظ في المجمو عة الثالثة تر اجع ملحوظ في التغيرات السابقة مع انخفاض ذو دلالة احصائية في متوسط النسبة المئوية لمساحة الياف الكو لاجين مقارنة بالمجموعة الثانية. ظهرت في المجموعة الر ابعة الالياف العضلية بشكل صحي و ترنيب طبيعي وكانت غير ذات دلالة احصائية في متوسط النسبة المئوية لالياف الكو لاجين مقارنة بالمجموعة الاولي ولقد عكست الدراسة الهستوكيميائية المناعية لكل المجمو عات ان مجموعة اللوسارتان ومجموعة الخلايا الجذعية تفاعل ايجابي مقارنة بمجموعة الدكسوروبسين كما اظهرت الخلايا الجذعية المزيد من الزيادة في التفاعل الايجابي عنه في مجموعة اللوسارتان الاستتتاج: ولقد وجد ان عقار اللوسارتان يحسن من اصابة عضلة القلب وان كان له تاثير ضئيل علي تجدد خلاياه بينما وجد ان للخلايا الجذعية امكانية و اعدة في تجدد عضلة القلب. 